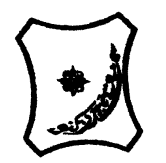

Bayero Journal of Pure and Applied Sciences, 13(1): 121 - 129

Received: April, 2020

Accepted: June, 2020

ISSN $2006-6996$

\title{
DEPOSITIONAL SETTING OF THE LATE CENOMANIAN TO EARLY TURONIAN SEDIMENTS OF YOLA SUB-BASIN, NORTHERN BENUE TROUGH, NIGERIA: FROM LITHOFACIES AND PALYNOFACIES
}

\author{
Sarki Yandoka, B. M. \\ ${ }^{1}$ Department of Geology, Bayero University, P.M.B. 3011 Kano, Nigeria \\ Corresponding Author, E-mail:bmsydgombe@gmail.com
}

\section{ABSTRACT}

Lithofacies and palynofacies studies was conducted on the Late Cenomanian to Early Turonian sediments of Dukul Formation from the Yola Sub-basin, Northern Benue Trough, northeastern Nigeria. This is with the aim to determine the paleodepositional environment of the studied sediments. Based on lithofacies analysis, three (3) facies were identified; shale, mudstone and limestone lithofacies. The sediments were inferred to have been deposited in shallow marine (shelf) environment below the mean fair-weather wave base (FWWB). Palynofacies analysis also suggest a distal oxic-dysoxic to relatively anoxic shelf environmentthat was responsible for the deposition of the sediments. This is in agreement with the shallow marine depositional environment as shown from lithofacies. The distal dysoxic condition could have been due to the sea-level drop of the continental shelf.

Keywords: Shallow Marine; Lithofacies; Palynofacies; Dukul Formation; Yola Sub-basin

\section{INTRODUCTION}

The Benue Trough is an intra-continental rift sedimentary basin (Sarki Yandoka et al., 2014; Abubakar, 2014). The Northern Benue Trough is divided into the Gongola and Yola Sub-basins (Fig. 1). The sedimentsconsist of gravels, sandstones, shales and limestones. The sediments were deposited incontinental to coastal -shallow marine depositional complexes ranging in age from Cretaceous to Tertiaryin association with Tertiary volcanic plugs (Nwajide, 2013; Carter et al., 1963; Abubakar, et al., 2008; Sarki Yandoka et al., 2014).The Cretaceous Dukul Formation was recognized asa sequences of "Limestone - Shale Series" andassigned to the Lower Turonian(Falconer, 1911; Carter et al., 1963; Guiraud, 1990, 1992; Kogbe, 1976).The formation consists of clays, shale, siltstones and thick limestone interbedded with shales (Ojo and Akande, 2000; Nwajide, 2013; Sarki Yandoka, 2015). Thesequences represent part of the shallow-marine(shelf) sedimentation in the Yola Sub-basin(Sarki Yandoka, 2015).

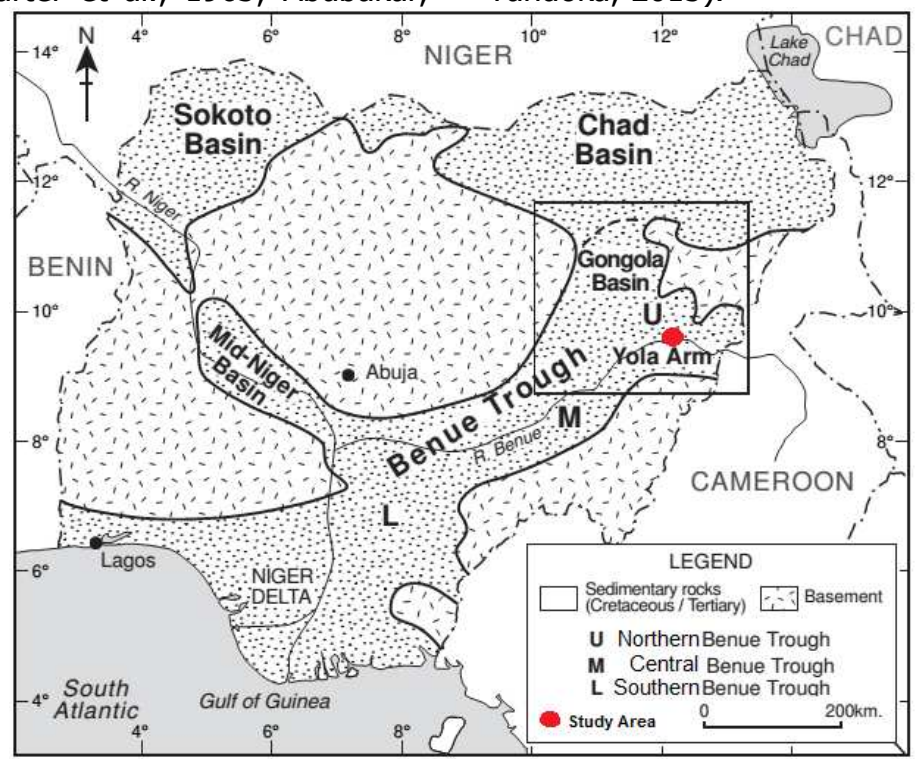

Figure 1: Generalised geological map of Nigeria showing the location of the study area (slightly modified after Abubakar, et al. 2008) 
BAJOPAS Volume 13 Number 1, June, 2020

Facies studies was conducted onthe continental to coastal shallow-marine Cretaceous successions of the Yola Sub-basin (e.g. Carter et al., 1963; Abubakar, 2014; Sarki Yandoka, 2015; Tukur et al., 2015; Sarki Yandoka et al., 2019 and among many others). However, studies related to lithofacies and palynofacies on the these sediments is lacking. The current study present the lithofacies and palynofaciesof the Late Cenomanian-Early Turonian sediments of Yola Sub-basin. This is with an objective ofreinterpreting the paleodepositional environment of the successions which could be used for future studies related to sequence stratigraphic and tectonostratigraphic reconstruction of the Northern Benue Trough.

\section{Geology}

The Nigerian Benue Trough was formed during the Early Cretaceous rifting and strike-slip faulting or movement of the Central West African Basement Complex (Carter et al., 1963; Abubakar, 2014; Benkhelil, 1983; 1989). Authors such Grant (1971), Kogbe (1976), Benkhelil (1989) and many others suggested rifting and strike-slip fault as the basis for the evolution of the Benue Trough. The most widely acceptable evolutionary model for Benue Trough is that of Grant, (1971). The Benue Trough trendsnortheast-southwest for about $1000 \mathrm{~km}$ in length and about $150 \mathrm{~km}$ average in its width. It is bounded by Niger Delta Basin at the southern end of the trough and the Chad (Bornu) Basin in the northern end. The trough contains thick Cretaceous-Cenozoic sedimentary profile for up to $6000 \mathrm{~m}$ associated with volcanics.

Based on geographical view, the Benue Trough is divided into Southern (Lower), Central (Middle) and Northern (Upper) benue basins (Zaborski, et al., 1997; Nwajide, 2013; Sarki Yandoka et al., 2014; Sarki Yandoka, 2015). The Northern or Upper Benue Trough consist of the
N-S trending Gongola Sub-basin and E-W trending Yola Sub-basin. The geology and stratigraphy of the Northern Benue Trough were described in detail by earlier workers such as Carter et al., (1963), Abubakar, (2014), Sarki Yandoka et al., (2014), Ojo and Akande (2000), Sarki Yandoka, (2015) and among many others. The stratigraphic succession of the Yola Subbasin (Fig. 2) comprises ofthe ?BerremianAptian to Albian continental sediments of Bima Formation. The Bima Formationconsist of mainly cobbles, gravels, sandstones and shales/clays. Recent authors (e.g. Sarki Yandoka, 2015; Tukur et al., 2015) sub-divided into two members; Lower Bima (B1) and Upper Bima (B2) members.

The Bima Formation is overlying by the Cenomanian transitional coastal and shallow marine sediments of Yolde Formation. The Cenomanian Yolde Formation consists of sandstones, clays and occasionally calcereous materials (Sarki Yandoka et al., 2015). The sediments were succeeded by the marine Late Cenomanina - Turonian - Coniacian sequences of the Dukul, Jessu and Sekuliye Formations and Numanha Shales (Sarki Yandoka et al., 2019). These shallow marine sediments are the lateral equivalents of Pindiga and Gongila Formations in the Gongola Sub-basin (Abubakar, 2014). The Lamja Formation is a delta sequences and it overlies the Numanha Shales and marked the end of sedimentation in the Yola Sub-basin (Fig. 2). The Dukul Formation generally consists of bedded shales and fossiliferous limestone (Carter et al., 1963). The formation was dated as Early to basal Middle Turonian based on evidences of ammonites. Based on microfaunal assemblage, the formation was interpreted as deposition in littoral to open marine shelf environments (Ojo and Akande, 2000). 
BAJOPAS Volume 13 Number 1, June, 2020

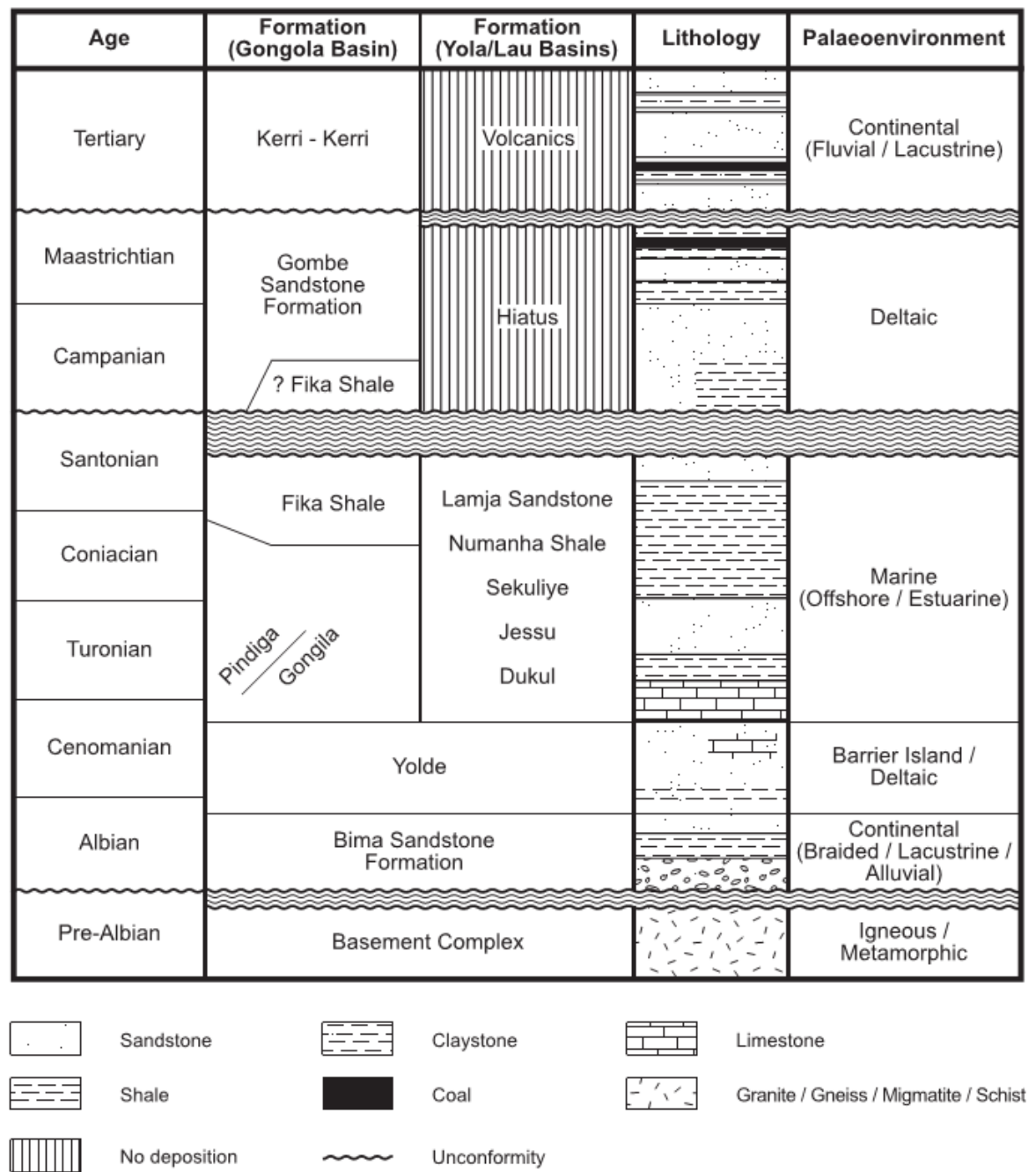

Figure 2: Stratigraphic succession of the Northern Benue Trough (after Abubakar, 2014)

\section{MATERIALS AND METHODS}

Fieldwork was conducted on the exposed sediments of Dukul Formation in the Yola Subbasin. Outcrops were logged (Fig. 3) and described for facies studies. Sedimentary features, color, textural, trace or body fossils and thicknesses of beds were studied. The identified sedimentological features allows forlithofacies analysis. A total of ten (10) shale samples were collected within the lithostratigraphic sections. The shale samples were grinded to fine powder using mortar and pestle. About $20 \mathrm{~g}$ of each sample was used for acid treatment using a diluted $95 \%$ HF concentration to remove silicates and later, $10 \%$ of $\mathrm{HCl}$ to remove the carbonates. The residue was decant until $\mathrm{Ph}$ is equal to 7 . The isolated kerogen was separated from the remaining samples using a mixture of zinc bromide $\left(\mathrm{ZnBr}_{2}\right)$ and later, was washed with distilled water for seven times and the residue was kept in oven for slide preparation. Palynofacies slides were prepared from the remaining residue after drying. The slides were placed on hotplate using Aldrich Canada balsam and were studied using the Leica DM 6000M transmitted light microscope (X20 objective) in the Department of Geology, University of Malaya, Malaysia. 


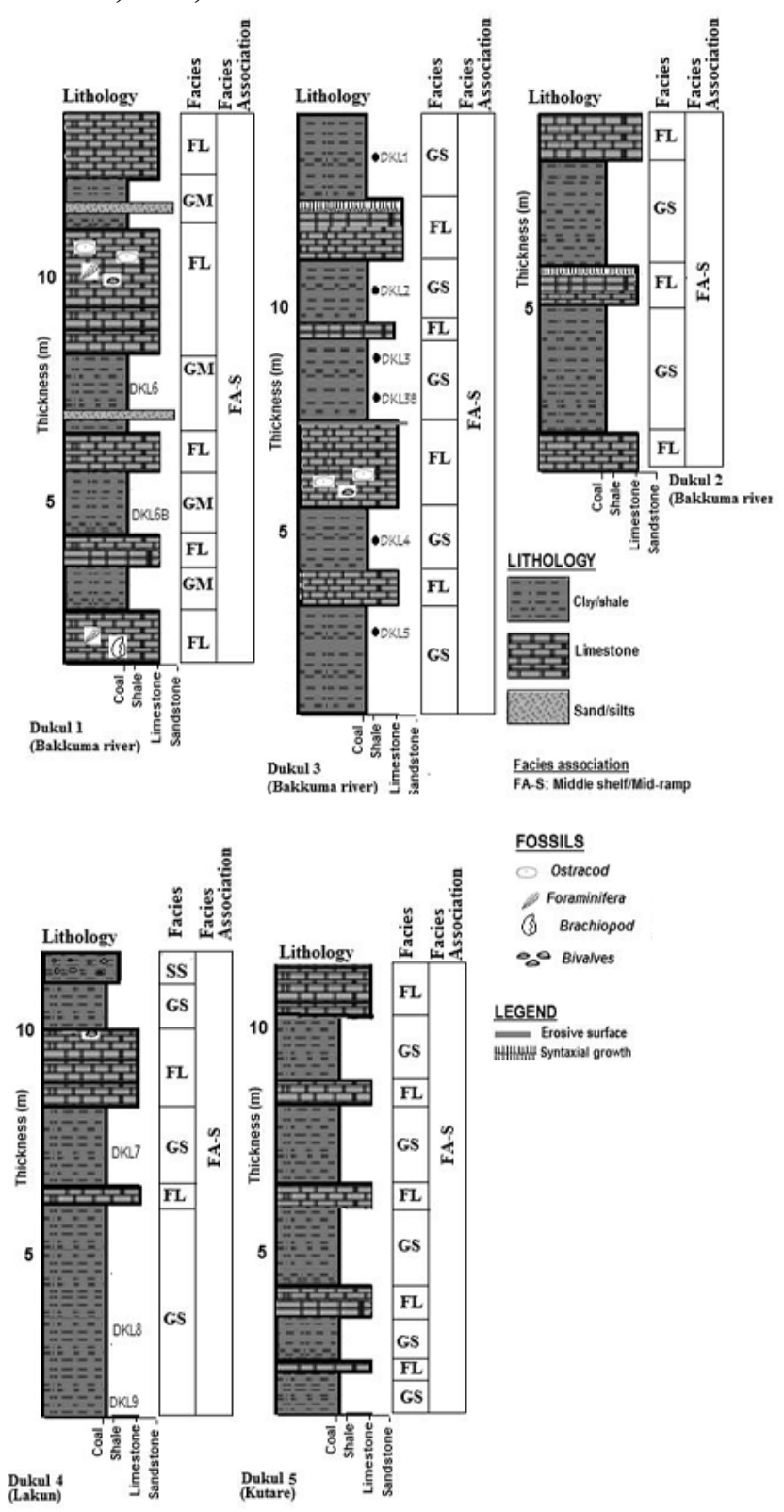

Figure 3: Lithostratigraphic sections of the Dukul Formation based on this study

\section{RESULTS AND DISCUSSIONS \\ The lithofacies interpretations}

The sediments identified in the study areas composed of mainly sandstones, siltstones, clays and shales and are widely distributed in all the logged sections. Following the method of modern day sedimentary facies analysis (e.g. Tucker, 1985; Miall, 1996; Dalrymple, 2010; Nichols, 2009; Walker, 1984; Walker and Plint, 1992; Anan, 2014), the studied sections consists of three lithofacies: shale (GS), mudstone (GM) and limestone (FL) facies.

(i) Clay-Shale facies (GS)

This facies consists of mainly shale units as the main lithology among all the identified silicilastic lithofacies (Fig. 4). The shale facies varies in color from grey, black, greyish yellow, gypsiferous, calcareous, occasionally glauconitic and perhaps fossiliferous in nature. It has a thickness of about 4-6 m and laterally traceable up to 30 meters. It is interbedded with fossiliferous limestone facies. Bioturbations are generally uncommon. The GS facies is interpreted as deposition in a low-energy environment under very low rate of sedimentation and low storms activity.

Similar facies were interpreted as deposits form due to suspension in the absence of wave and current structures (Nichols, 2009; Anan, 2014). Minor gypsiferous appearance may also suggest arid climatic conditions during deposition. 
BAJOPAS Volume 13 Number 1, June, 2020

(ii) Mudstone facies (GM)

This facies consists of mudstone that is lightgreyto grey in color and sometimes brownish (Fig. 4). The mudstone is generally intercalated with sandstone and siltstones that are calcareous and perhaps, glauconitic in nature. The facies has a thickness ranging from 0.7 $2.5 \mathrm{~m}$ and is laterally extensive. The mudstone facies is also interbedded with the fossiliferous limestone (carbonate) facies with well developed syntaxial calcite growth. Body fossils are rare but they some are found as sparse fragments within the logged sections. The facies is interpreted as deposits by the suspended sedimentationand low-energy currents in a relatively shallow marine or shelf setting accumulated under the fair-weather wave base perhaps, above the storm wave base (Walker and Plint, 1992; Plint, 2010). (iii) Fossiliferous limestone facies (FL)

The limestone facies range in color from grey to light brownish-grey consisting wackestone, packestone and mudstone with a thickness ranging from $3.5-7 \mathrm{~m}$ or even more (Fig. 4). The upper and lower contacts of this facies is erosional or perhaps, brecciated interbedded with shale (GS) and mudstone (GM) lithofacies. Macrofossils range in sparse to relatively abundant including Brachiopods, Bivalves, Foraminifera and Ostracods (Figs. 3 and 4).This facies is interpreted as deposit that formed in a low-energy shallow marine shelf or ramp depositional setting (e.g.Bauer, 2002). The appearance of brecciations, mud matrix, glauconitic tint, faunal abundance may perhaps suggests a shallow water depositional environment that formed below the fair weather wave base (Plint, 2010; Anan, 2014).
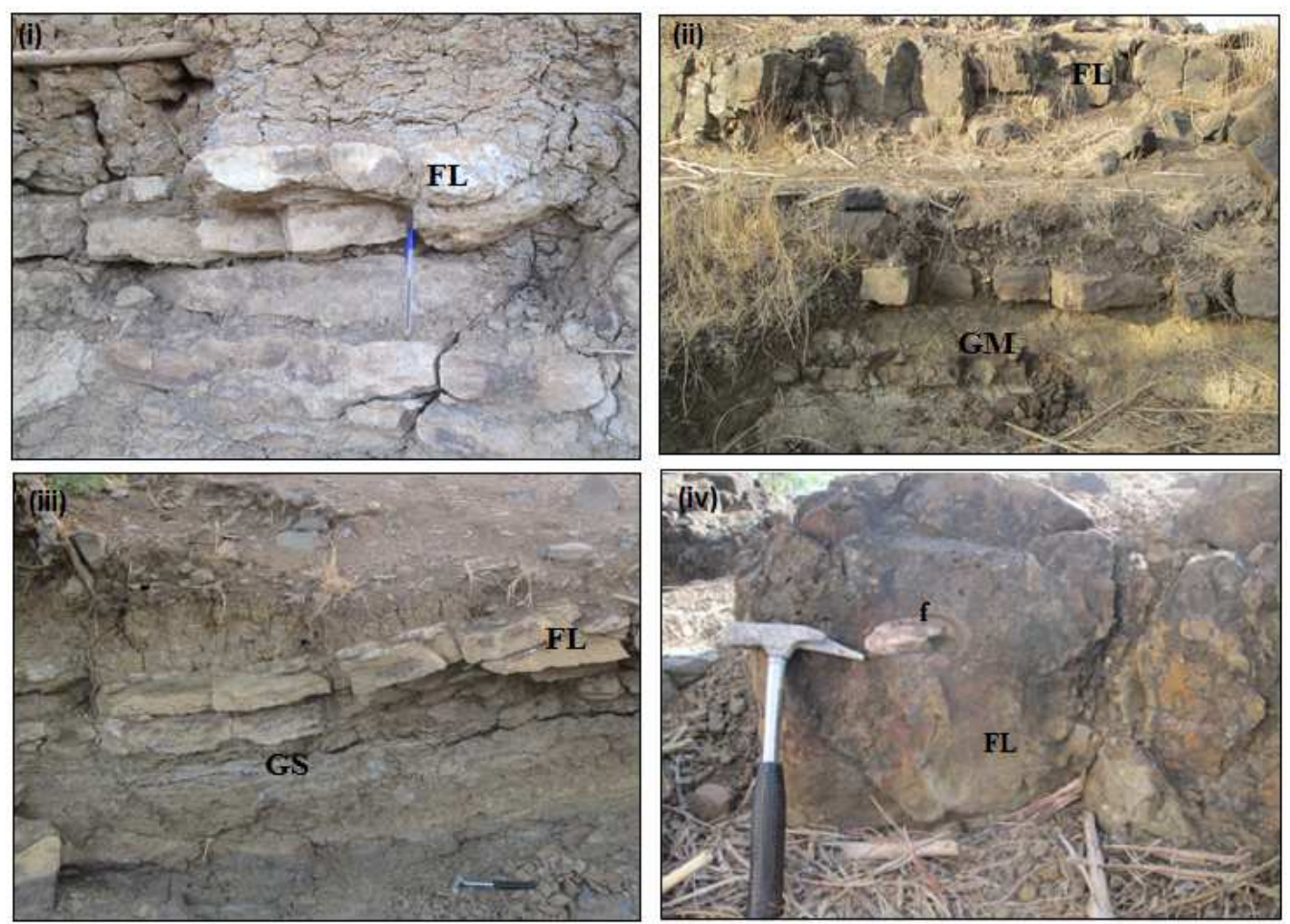

Figure 4: Field photographs depicting the facies; (i) fossiliferous limestone, (ii) fossiliferous limestone and mudstone, (iii) fossiliferous limestone and clay/shale and (iv) fossiliferous limestone and macrofossils

\section{The palynofacies interpretations}

Palynofacies of isolated kerogen was conducted using fluorescence and transmitted lights microscopy with an objective of determining the abundance of three major kerogen groups: AOM (amorphous organic matter), Ph (phytoclasts) (Ph) and PAL (palynomorphs).

(i) Palynofacies A: Phytoclast group

This composed of woody tissue and cuticles which are generally derived from higher plants from terrestrial environments (e.g. Tissot and Welte, 1978, 1984; Tyson, 1993, 1995). From the studied samples, the phytoclast includes translucent non-biostructured and translucent banded biostructured that ranges from 12 $15 \%$ (Fig. 5). Some of the phytoclast are dark in color. This could be due to high thermal maturity experienced by the samples. 

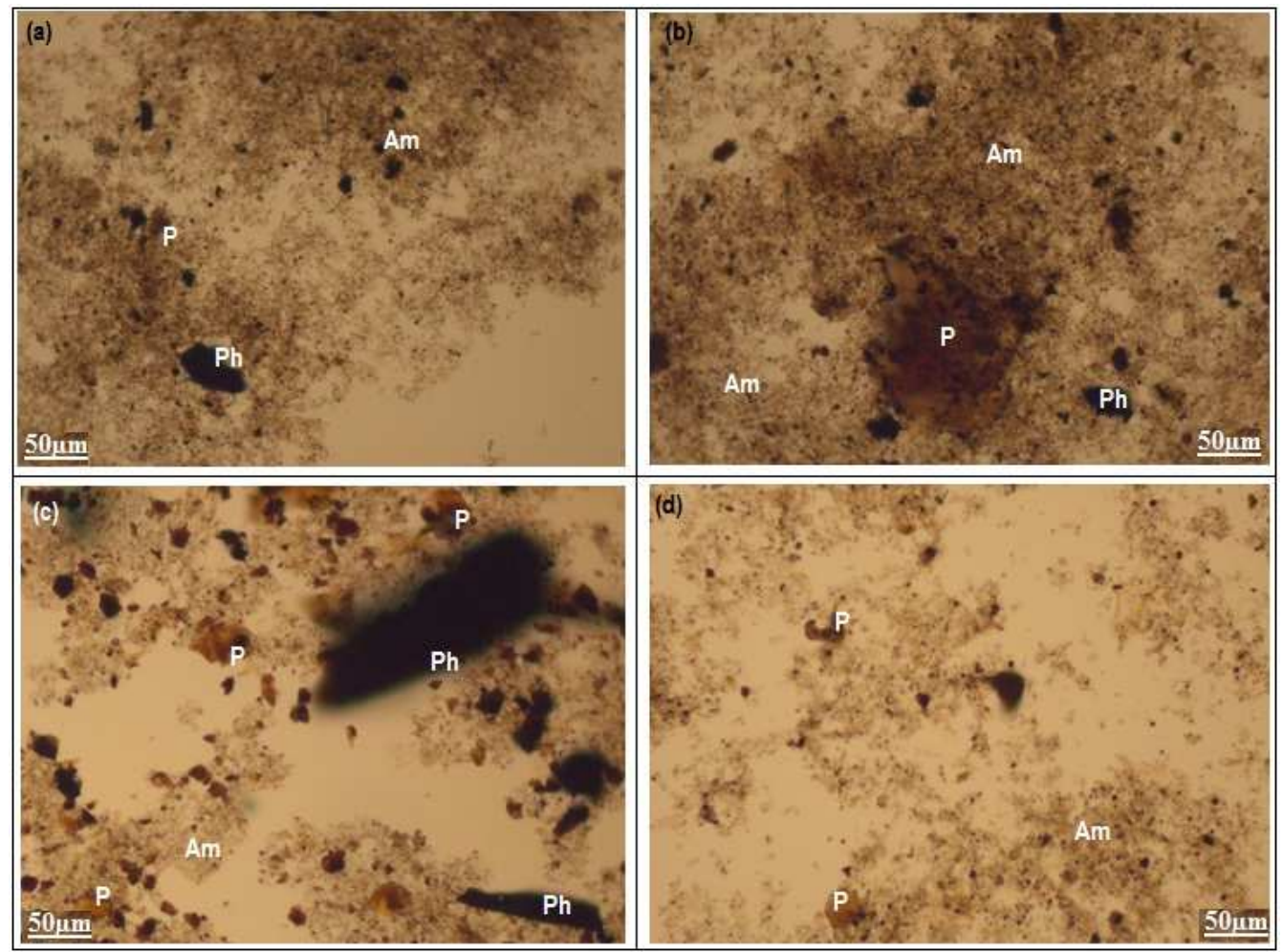

Figure 5: Photomicrographs of palynofacies showing amorphous organic matter (Am), phytoclast $(\mathrm{Ph})$ and palynomorphs $(\mathrm{P})$

\section{(ii) Palynofacies B: Amorphous organic matter group}

This composed of amorphous organic matter derived from bacteria, phytoplankton and remnants or products of resins and tissues (Tyson, 1995). The phytoplanktons composed of heterogeneous or homogeneous particles and perhaps, structureless. From the analysed samples, the amorphous organic matteris higher in concentration in the range $79-84 \%$ (Fig. 5). It shows abundant terrestrial materials and weak fluorescence under microscopy.More so, some of the samples are organically lean due to high thermal alteration.

\section{(iii) Palynofacies C: Palynomorphs group}

This composed of palynomorphs showing highly degreded trilobete and monolete spores. They are less abundant (Fig. 5) and their ratios ranges from $6-7 \%$. Most of the studied samples are highly degraded and shows weak to non-fluorescence under microscopy. The palynomorphs are found to be present in very low concentration.

\section{Depositional setting}

Lithofacies investigation allows interpretation of the facies succession (a mega-depositional environment) as shallow marine (shelf). Based on clasticity index and facies characteristics, the energy of deposition was determined. Authors such as Carter et al. (1963) Genik, (1993), Guiraud, (1993) Sarki Yandoka et al. (2014) and many others reported that during the Cenomanian, major marine transgression affected the entire Benue Trough. The transgression also matched with the regional and global sea-level rise (Anan, 2014; Haq et al., 1987). The Cenomanian marine transgression in the Benue Trough was responsiblefor deposition of the transitional Yolde Formationconformably on the continental Bima Formation.

This study therefore, suggests that as the transgression progresses, sediments e.g. siltstones, clay/shales, mudstone and limestone with fossils e.g. brachiopods, corals, oysters, ostracod, ammonites, foraminifera and bivalves prevailed as "Limestone-Shale Series" of the Dukul Formation. Further sequences were represented by the brief regressive shoreface of Jessu Formation (Sarki Yandoka et al., 2019). The shallow marine facies of the Cenomanian Yolde Formation gradually transformed into a carbonate dominated environment (Fig. 6), most probably due to the relative sea-level rise which continued resulting in the development of a deeply entrenched carbonate shallow marine shelf environment of the Dukul Formation. 


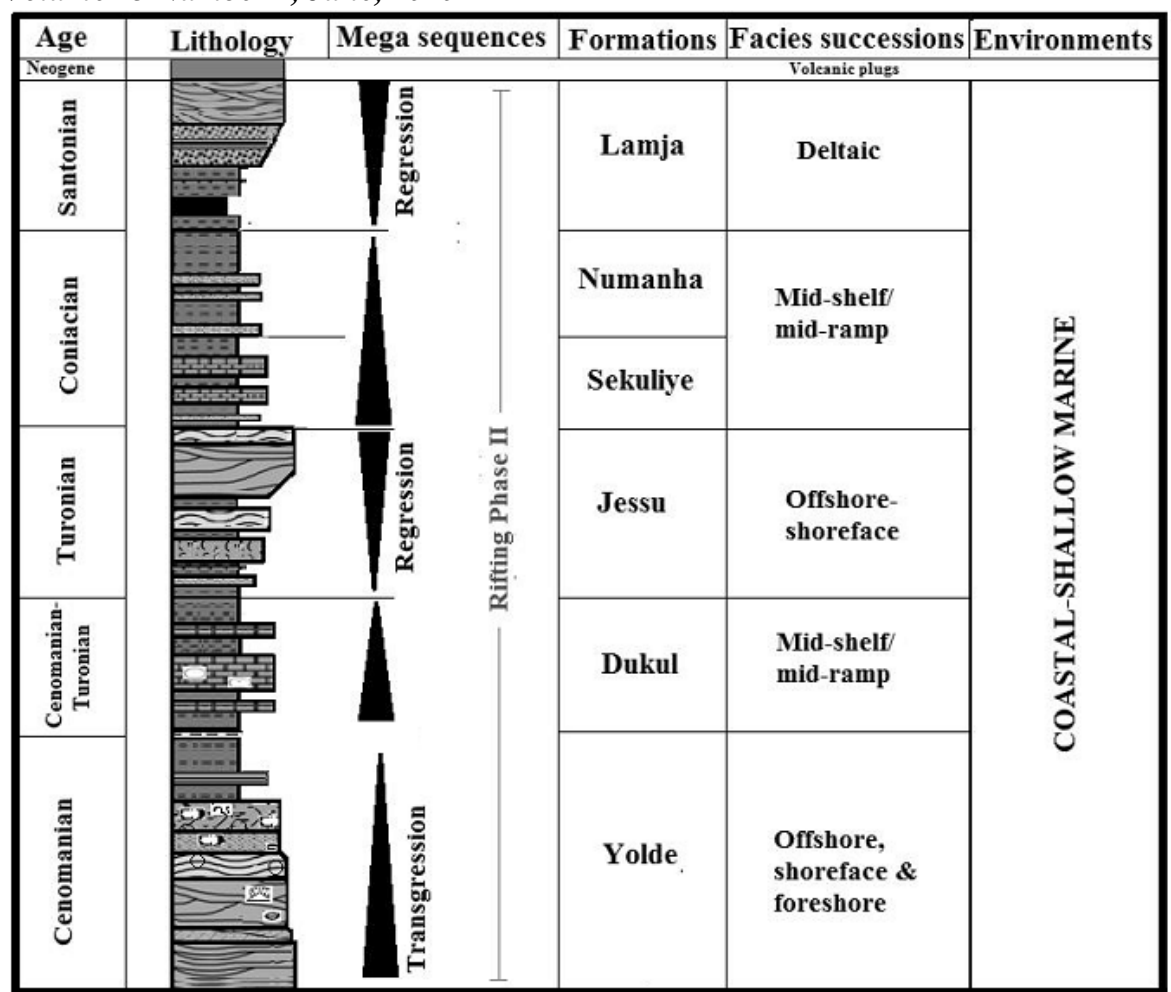

Figure 6: Coastal-shallow marine sequences of Yola Sub-basin showing the Yolde and Dukul formations deposited during Rifting Phase II

\section{CONCLUSIONS}

Lithofacies and palynofacies investigation of the Cretaceous sequences of Dukul Formation from Yola Sub-basin of the Northern Benue Trough northeastern Nigeriahas shown that the sediments were deposited in shallow marine (shelf) environment. This study also confirm that the coastal-shallow marine Cenomanian Yolde Formation had gradually transformed into a carbonate dominated setting due to the relative

\section{REFERENCES}

Abubakar, M.B., Dike, E.F.C., Obaje, N.G., Wehner, H., Jauro, A., (2008). Petroleum prospectivity of Cretaceous Formations of Gongola Basin, Upper Benue Trough, Nigeria; An organic geochemical perspective on a migrated oil controversy. Journal of Petroleum Geology 31(4), $387-408$.

Abubakar, M.B., 2014. Petroleum Potentials of the Nigerian Benue Trough and Anambra Basin: A Regional Synthesis. Natural Resources, 5(1), 25-58.

Anan, T., (2014). Facies analysis and sequence stratigraphy of the CenomanianTuronian mixed siliciclastic- carbonate sediments in west Sinai, Egypt. Sedimentary Geology 307, 34-46.

Bauer, J., 2002. Late Cenomanian-Santonian carbonate platform evolution of Sinai rise in sea-level which results in the development of carbonates of the Dukul Formation. Palynofacies indicate distal oxicdysoxic to relatively anoxic shelf environment which is in agreement with shallow marine (shelf) environment. The presence of marine palynomorphs indicates distal dysoxic shelf environment whilst non-opaque phytoclast suggests distal dysoxic environment.

(Egypt): stratigraphy, facies, and sequence architecture. Berichte, Fachbereich Geowissenschaften, Universitat Bremen 191 (178 pp.).

Benkhelil, J., (1989). The origin and evolution of the Cretaceous Benue Trough (Nigeria). Journal of African Earth Science 8, 251282.

Carter, J.D., Barber, W., Tait, E.A., Jones, G.P., 1963. The geology of parts of the Adamawa, Bauchi and Bornu Provinces in Northeastern Nigeria. Geological Survey Nigerian Bulletin 30, 53-61.

Dalrymple, R.W., (2010). Interpreting sedimentary successions: facies, facies analysis and facies models, in: James, N.P., Dalrymple, R.W. (Eds.), Facies Models 4. Geological Association of Canada, St. John's Newfoundland, pp. 318. 
BAJOPAS Volume 13 Number 1, June, 2020

Falconer, J.D., (1911). The Geology and Geography of Northern Nigeria. Macmillian: London, UK. 147- 154.

Genik, G.J., (1993). Petroleum geology of Cretaceous-Tertiary rift basins in Niger, Chad, and Central African Republic. American Association of Petroleum Geologists Bulletin 77, 1405-1434.

Grant, N. K., (1971). South Atlantic, Benue Trough and Gulf of Guinea Cretaceous triple junction. Bulletin Geological Society America 82, 2295-2298.

Guiraud, R., Maurin, J. E., 1992. Early Cretaceous rifts of Western and Central Africa: an overview, in: P.A., Ziegler, (Eds.), Geodynamics of Rifting, Volume II. Case History Studies on Rifts: North and South America and Africa. Tectonophysics, 213, 153-168.

Guiraud, M., 1990. Tectono-sedimentary frameworks of the Early Cretaceous continental Bima Formation (Upper Benue Trough, NE Nigeria). Journal of African Earth Sciences 10, 341 -353.

Kogbe, C.A., 1976. Paleogeographic history of Nigeria from Albian times, in: Geology of Nigeria, Kogbe, C.A., (Eds.). Elizabethan Publishers, Lagos, Nigeria, pp: 237-252.

Haq, B.U., Hardenbol, J., Vail, P.R., 1987. Chronology of fluctuating sea levels since the Triassic. Science 235, 11571167.

Miall, A.D., 1996. The Geology of Fluvial Deposits, Sedimentary Facies, Basin Analysis, and Petroleum Geology: New York, Springer, pp. 582.

Nichols, G.J., 2009. Sedimentology and stratigraphy. John Wiley and Sons, New York, 452p.

Nwajide, C.S., 2013. Geology of Nigeria's Sedimentary Basins.CSS Bookshops Ltd., Lagos, Nigeria, 565pp.

Ojo, O.J., Akande, S.O., (2000). Depositional environment and diagenesis of the carbonate facies of Dukul and Jessu Formations in the Yola Basin, NE Nigeria: Implication for reservoir potential. NAPE Bulletin, Vol 15 (1), 47 59.

Plint, A.G., (2010). Wave-and storm-dominated shoreline and shallow-marine systems. In Facies Models 4, edited by James, N.P. \& Dalrymple, R.W. Geological Society of Canada, St. John's. pp. 167200.

Sarki Yandoka B.M., Abubakar M.B., Abdullah, W.H., Amir Hassan M.H., Adamu, B.U., Jitong, J.S., Aliyu, A.K., Adegoke, K.A., (2014). Facies analysis, palaeo environmental reconstruction and stratigraphic development of the Early Cretaceous sediments (Lower Bima Member) in the Yola Sub-basin, Northern Benue Trough, NE Nigeria. Journal of African Earth Sciences 96, 168-179.

Sarki Yandoka, B.M., (2015). Sedimentary and organic facies characterisation of the Cretaceous sequences, Yola Sub-basin, Northern Benue Trough, NE Nigeria. Unpublished PhD thesis, University of Malaya, Kuala Lumpur, Malaysia.

Sarki Yandoka, B.M., Abdullah, W.H., Abubakar, M.B., Hakimi, M.H., Mustapha, K.A., Adegoke, K.A., (2015a). Organic geochemical characteristics of Cretaceous Lamja Formation from Yola Sub-basin, Northern Benue Trough, NE Nigeria: implication for hydrocarbongenerating potential and paleodepositional setting. Arabian Journal of Geosciences, DOI 10.1007/s12517-014-1713-3.

Sarki Yandoka, B.M., Abdullah, W.H., Abubakar, M.B., Hakimi, M.H., Adegoke, A.K., (2015b). Geochemical characterisation of Early Cretaceous lacustrine sediments of Bima Formation, Yola Sub-basin, Northern Benue Trough, NE Nigeria: Organic matter input, preservation, paleoenvironment and palaeoclimatic conditions. Marine and Petroleum Geology 61, 82 - 94.

Sarki Yandoka, B.M., Abdullah, W.H., Abubakar, M.B., Hakimi, M.H., Adegoke, A.K., (2015c). Geochemistry of the Cretaceous coals from Lamja Formation, Yola Sub-basin, Northern Benue Trough, NE Nigeria: Implications for paleoenvironment, paleoclimate and tectonic setting. Journal of African Earth Sciences 104, 56-70.

Sarki Yandoka, B.M., Abdullah, W.H., Abubakar, M.B., Hakimi, M.H., Jauro, A., Adegoke, K.A., (2016). Organic geochemical characterisation of shallow marine Cretaceous formations from Yola Subbasin, Northern Benue Trough, NE Nigeria. Journal of African Earth Sciences 117, $235-251$

Sarki Yandokaa, B.M., Abdullah, W.H., Abubakar, M.B., Johnson, H., Adegoke, K.A., Arabi, A.S., Bata, T., Amir Hassan, M.H., Mustapha, K.A., Usman, M.B., (2019). Shoreface facies model of Cretaceous Jessu Formation, Yola Subbasin, Northern Benue Trough, northeast Nigeria: New insights from 
BAJOPAS Volume 13 Number 1, June, 2020 facies analysis and molecular geochemistry. Journal of African Earth Sciences 152, 10-22.

Scholle, P.A., Ulmer-Scholle, D.S., 2003. A color guide to the petrography of carbonate rocks: grains, textures, porosity, diagenesis. AAPG Memoir 77

Tucker, M.E., (1985). Shallow-marine carbonate facies and facies models. Geological Society, London, Special Publications, 18, 147-169.

Tukur, A., Samaila, N.K., Grimes, S.T., Kariya, I.I., Chaanda M.S., (2015). Two member subdivision of the Bima Sandstone, Upper Benue Trough, Nigeria: Based on sedimentological data. Journal of African Earth Sciences 104, 140-158.

Tyson, R.V., (1993). Palynofacies analysis. In: Applied Micropaleontology, Jenkins, D.G. (Ed.), Kluwer Academic Publishers. The Netherlands, Amsterdam, pp. 153-191.

Tyson, R.V., (1995). Sedimentary Organic Matter. Organic facies and palynofacies. Chapman and Hall, Londons, 615 pp.
Walker, R.G., (1984). Shelf and shallow marine sands. In: Walker, R.G., (Ed), Facies Models, Geosciences Canadian Reprint Series, 1, 141-170.

Walker, R., Plint, A.G., (1992). Chapter 12: Wave- and storm-dominated shallow Marine systems. Facies models, response to sea level change. R. J. Walker, N. P. Ontario, Canada. In: Walker, R., James, N. (Eds.), Facies Models, Response to Sea Level Change, pp. 219-238.

Wilson, J.L., 1975. Carbonate Facies in Geologic History. Springer-Verlag, New York, Heidelberg, Berlin.

Wright, V.P., Burchette, T.P., (1996). Shallowwater carbonate environments: in Reading, H. L., ed., Sedimentary Environments: processes, facies, and stratigraphy (third edition). 